Cytogenet Genome Res 1987;44:I-IV

Contents, Vol. 44, 1987

S. Karger - Medical and Scientific Publishers • Basel • München • Paris • London • New York • New Delhi • Singapore • Tokyo • Sydney

Drug Dosage

The authors and the publisher have exerted every effort to ensure that drug selection and dosage set forth in this text are in accord with current recommendations and practice at the time of publication. However, in view of ongoing research, changes in government regulations, and the constant flow of information relating to drug therapy and drug reactions the reader is urged to check the package insert for each drug for any change in indications and dosage and for added warnings and precautions. This is particularly important when the recommended agent is a new and/or infrequently employed drug.

All rights reserved.

No part of this publication may be translated into other languages, reproduced or utilized in any form or by any means, electronic or mechanical, including. photocopying, recording, microcopying, or by any information storage and retrieval system, without permission in writing from the publisher or, in the case of photocopying, direct payment of a specified fee to the Copyright Clearance Center (see 'Information for Readers and Subscribers').

(C) Copyright 1987 by S. Karger AG, P.O. Box, CH-4009 Basel (Switzerland) Printed in Switzerland by Buchdruckerei Schüler AG, Biel

Contents Vol. 44,1987

No. 1

Editorial

Gene nomenclature

KlingerHP Obituary

Menasche Marcus

Original Articles

Mapping of the gene for anti-Müllerian hormone to the short arm of human chromosome 19 


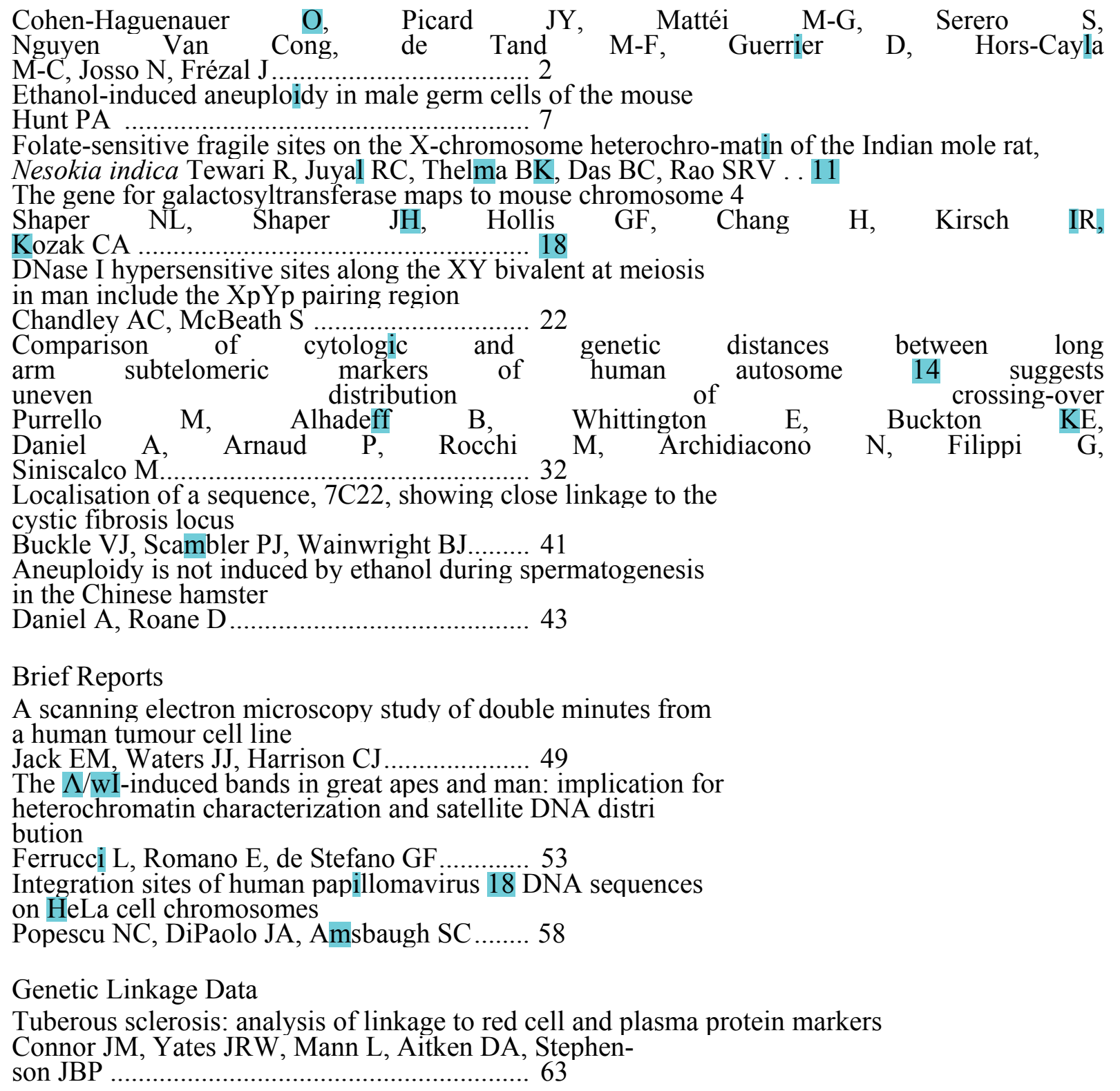

\section{No. 2-3}

Original Articles

Mapping of the oncogenes Myc, Sis, and int- 1 to the distal part of mouse chromosome 15

Adolph S, Bartram CR, Hameister H.

Cytogenetic studies of Hynobiidae (Urodela). VI. R-banding

patterns in five pond-type Hynobius from Korea and

Japan

Kuro-o M, Ikebe C, Kohno S 69

Genetic mapping of Prm-1, Igl-1, Smst, Mtv-6, Sod-1, and Ets-2 and localization of the Down syndrome region on mouse chromosome 16 
Reeves RH, Gallahan D, OHara BF, Callahan R, Gear-

Gene assignments and syntenic groups in the sacred baboon

(Papio hamadryas)

Thiessen KM, Lalley PA.................................. 82

Sex linkage of muscle creatine kinase in Harris' hawks

Morizot DC, Bednarz JC, Ferrell RE................ 89

Mapping polypeptide hormone genes in the mouse: somatosta-

tin, glucagon, calcitonin, and parathyroid hormone

Lalley PA, Sakaguchi AY, Eddy RL, Honey NH, Bell GI,

Shen L-P, Rutter WJ, Jacobs JW, Heinrich G, Chin WW,

NaylorSL 92

The rat vitamin D binding protein (Gc-globulin) gene is syn

tenic with the rat albumin and $\alpha$-fetoprotein genes on chro

mosome 14

Cooke NE, Levan G, Szpirer J

98

Regional localization of three probes closely linked to the cys

tic fibrosis locus by deletion analysis

Wainwright BJ, Scambler PJ, Williamson R....101

The nature of the $1 ; 29$ translocation in cattle as revealed by

synaptonemal complex analysis using electron micros

copy

Switoński M, Gustavsson I, Plöen L

IV

Contents

Localization and linkage of three polymorphic DNA sequences on human chromosome 20

Goodfellow PJ, Duncan AMV, Farrer LA, Holden JJA,

White BN, Kidd JR, Kidd KK, Simpson NE .. 112

$\begin{array}{lll}\text { Expression of fragile X in human-mouse } & \text { somatic } & \text { cell hybrids } \\ \text { Lin MS, Shimanuki K, Wilson MG................118 }\end{array}$

Lin MS, Shimanuki K, Wilson MG ................ 118

Chromosomal evolution of the Canidae. I. Species with high

diploid numbers

Wayne RK, Nash WG, O’Brien SJ

123

Chromosomal evolution of the Canidae. II. Divergence from

the primitive carnivore karyotype

Wayne RK, Nash WG, O'Brien SJ ................ 134

A somatic cell hybrid with a single human chromosome 22 corrects the defect in the $\mathrm{CHO}$ mutant (Ade $-\mathrm{I}$ ) lacking ade-nylosuccinase activity

Van Keuren ML, Hart IM, Kao F-T, Neve RL, Bruns GAP,

Kurnit DM, Patterson D.

142

A Robertsonian polymorphism in pink salmon (Oncorhynchus

gorbuscha) involving the nucleolar organizer region

Phillips RB, Kapuscinksi ARD 148

Re-evaluation of the sublocalization of esterase $\mathrm{D}$ and its relation to the retinoblastoma locus by in situ hybridization Duncan AMV, Morgan C, Gallie BL, Phillips RA, Squire J 153

Heterochromatic variation in Cebus apella (Cebidae, Platyr-

rhini) of different geographic regions

Matayoshi T, Seuanez HN, Nasazzi N, Nagle C, Armada

JL, Freitas L, Alves G, Barroso CM, Howlin E 158

Localization of the Hprt locus by in situ hybridization and distribution of loci on the mouse X-

chromosome Lyon MF, Zenthon J, Burtenshaw MD, Evans EP .... 163

Chromosomal localization of human endogenous retroviral

element ERV1 to $18 \mathrm{q} 22 \rightarrow \mathrm{q} 23$ by in situ hybridization

Renan MJ, Reeves BR 167

\section{Brief Report}


A mouse homeo box - containing gene maps near a develop mental mutation

Hill RE, Hall AE, Sime CM, Hastie ND.......... 171

\section{Genetic Linkage Data}

Exclusion of close linkage between the loci for cystic fibrosis and neuropeptide $\mathrm{Y}$ on human chromosome 7

Meisler MH, Spence JE, Dixon JE, Caldwell RM, Minth

CD, Beaudet AL................................................ 175

\section{Announcement}

International Standing Committee on Human Cytogenetic

Nomenclature 1986-1991 176

\section{No. 4}

\section{Original Articles}

Destabilization of the adenosine deaminase gene sequences in rat-rat somatic cell hybrids

Hoffee PA, Chiang J, Rowland P III 177

Differences in the location of nucleolus organizer regions in European vespertilionid bats

Volleth M 186

Problems in using Robertsonian rearrangements in determin ing monophyly: examples from the genera Tatera and Gerbillurus

Qumsiyeh MB, Hamilton MJ, Schlitter DA ...198

Enhancement and attenuation of cytogenetic damage by vita min $\mathrm{C}$ in cultured human lymphocytes exposed to Thiotepa or L-ethionine

Lialiaris T, Mourelatos D, Dozi-Vassiliades J.209

Variant Philadelphia translocations in chronic myeloid leu kemia

De Braekeleer M

Correlation of pachytene chromomeres and metaphase bands of human chromosomes, and distinctive properties of telomeric regions

Ambros PF, Sumner AT .223

\section{Brief Reports}

Offspring of a trisomic cow

Mayr B, Schellander K, Auer H, Tesarik E, Schleger W,

Sasshofer K, Glawischnig E

Localization of the human catalase and apolipoprotein A-I genes to chromosome 11

Schroeder WT, Saunders GF

The gene for human carbonic anhydrase II (CA2) is located at chromosome 8q22

Nakai H, Byers MG, Venta PJ, Tashian RE, Shows TB . 234

\section{Genetic Linkage Data}

A new human RFLP identified by 7D2 places D13S10 proximal to esterase D

Bowcock AM, Farrer LA, Hebert JM, Bonne-Tamir B,

Frydman M, Kidd KK, Cavalli-Sforza LL....... 236

Author Index

Subject Index 